\title{
Evaluation of 1753 patients treated with the diagnosis of tuberculosis
}

\section{Tüiberkülloz tanısıyla yatırılarak tedavi edillen 1753 hastanın değerlendirilmesi}

\author{
Mevlüit Karataș ${ }^{1}$, Tüilin Kuyucü ${ }^{2}$, Tüllin Sevimª ${ }^{3}$
}

Mesleki ve Çevresel Hastalıklar Hastanesi, Göğüs Hastalıkları Bölümü, Ankara, Turkey

${ }^{2,3}$ S.B.Ü Süreyyapaşa Gögüs Hastalıkları ve Göğüs Cerrahisi Eğitim ve Araştırma Hastanesi, İstanbul, Turkey

Corresponding author: Mevlüt Karataş, MD, Mesleki ve Çevresel Hastalıklar Hastanesi, Göğüs Hastalıkları Bölümü, Ankara, Turkey

E-mail: fmkaratas@yahoo.com

Received/Accepted: March 21, 2019 / March 26, 2019

Conflict of interest: There is not a conflict of interest.

\section{SUMMARY}

Objective: In this study, we aimed to evaluate the data of 1753 patients diagnosed with tuberculosis (TB) in Süreyyapaşa Chest Diseases and Chest Surgery Training and Research Hospital for one year.

Method: The study was planned as a single center retrospective. Patients diagnosed with TB were included in the study. Patient data were obtained from TB surveillance forms, bacteriology laboratory drug resistance database and octomed patient follow-up program.

Results: $\mathrm{N}=1146(65.4 \%)$ of the cases were male and $\mathrm{n}=607(34.6 \%)$ were female. The male/female ratio was 1.8 and the highest cases were observed in the $15-24$ age group in both sexes. $\mathrm{N}=1422(81 \%)$ of all cases were pulmonary $\mathrm{TB}$ (PTB) $(76.5 \%$ new case PTB), $\mathrm{n}=331$ (18.9\%) were extra pulmonary tuberculosis (EPTB) (pleural TB $86.1 \%$, TB lymphadenitis $10.6 \%$ ). Smear positivity rate was $78.7 \%$ only in patients with PTB. It was found that culture contributed $8.7 \%$ to the diagnosis. In our study, primary and secondary drug resistance was most frequently detected against $\mathrm{H}$; respectively $(20.2 \%, 34.7 \%)$. Total $\mathrm{R}$ primary and secondary resistance were $(7.6 \%, 22.4 \%)$ respectively. Primary and secondary resistance for HR were $(3.2 \%, 7 \%)$ respectively. Primary resistance to single drug was $15.4 \%$, primary resistance to double drug was $6.0 \%$, primary resistance to three drugs was $1.3 \%$, and primary resistance to four drugs was $2.7 \%$. Secondary resistance to single drug was $15.9 \%$, secondary resistance to double drug was $10.9 \%$, secondary resistance to three drugs was $4.3 \%$, and secondary resistance to four was $9.9 \%$. Primary and secondary resistance to multidrug were found respectively $(7.2 \%, 21.2 \%) .70 .5 \%$ of the patients who underwent resistance test were sensitive to all drugs.

Conclusions: This study is one of the largest series in a single center in our country. Smear positivity rates in patients with PTB were found to be higher than the data of our country. Drug resistance rates were found to be high due to referral of multidrug-resistant cases to our center.

Keywords: Tuberculosis, surveillance, primary resistance, secondary resistance

\section{ÖZET}

Amaç: Bu çalıșmada Süreyyapaşa Göğüs Hastalıkları ve Göğüs Cerrahisi Eğitim ve Araștırma Hastanesinde bir yıl içerisinde tüberküloz (TB) tanısıyla yatan 1753 hastanın verisini değerlendirmeyi hedefledik.

Yöntem: Çalışma tek merkezli retrospektif olarak planlandı. TB tanısı alan hastalar çalışmaya dahil edildi. Hasta verileri TB sürveyans formlarından, bakteriyoloji laboratuvarı ilaç rezistans veri tabanından ve octomed hasta takip programından elde edildi.

Bulgular: Olguların \%65.4'ü ( $\mathrm{n}=1146)$ erkek, \%34.6's1 $(\mathrm{n}=607)$ kadındı. Erkek/Kadın oranı 1.8:1 ve her iki cinsiyette 15-24 yaş grubunda en yüksek olgu sayısı görüldü. Tüm olguların \%81'i (n=1422) akciğer TB (\%76.5'i yeni olgu akciğer TB), \%18.9’u (n=331) akciğer dişı organ TB idi (plevra TB \%86.1, TB lenfadenit \%10.6). Sadece akciğer TB’lilerde yayma pozitiflik oranı \%78.7 saptandı. Kültürün tanıya \%8.7 ek katkı sağladığı görüldü. Çalışmamızda primer ve sekonder ilaç direnci en sık H’ye karşı saptand1; sırasıyla (\%20.2, \%34.7). Toplam R primer ve sekonder direnç sırasıyla (\%7.6, \%22.4), HR için primer ve sekonder direnç sırasıyla (\%3.2, \%7) saptandı. Tek ilaca primer direnç \%15.4, çift ilaca primer direnç \%6.0, üç ilaca primer direnç \%1.3, dört ilaca primer direnç \%2.7 olarak hesaplandı. Tek ilaca sekonder direnç \%15.9, çift ilaca sekonder direnç \%10.9, üç ilaca sekonder direnç $\% 4.3$, dört ilaca sekonder direnç \%9.9 idi. Çok 
ilaca primer ve sekonder direnç sırasıyla (\%7.2, \%21.2) saptandı. Direnç testi yapılan olguların \%70.5'i tüm ilaçlara hassast1.

Sonuç: Bu çalışma ülkemizde tek merkezde yapılmış en geniş serilerden biri olma özelliği taşımaktadır. Akciğer TB'lilerde yayma pozitiflik oranlarımız ülkemiz verilerinden daha yüksek tespit edilmiştir. Çok ilaca dirençli vakaların merkezimize sevk edilmesi nedeniyle ilaç direnç oranlarımız yüksek bulunmuştur.

Anahtar sözcükler: Tüberküloz, sürveyans, primer direnç, sekonder direnç

\section{INTRODUCTION}

Tuberculosis (TB) is one of the top ten causes of deaths in the world. It is reported that 1.6 million people died due to TB on the world in 2017. Ninety-five percent of these deaths occur in lowand middle-income countries. The regions with the highest incidence and mortality in the world are Africa and South East Asia. Turkey is located in the European Region of the World Health Organization (WHO) classification ${ }^{1}$.

Tuberculosis is a necrotizing granulomatous disease caused by mycobacterium tuberculosis, which is frequently involved in the lungs, including all the organs of the body ${ }^{2}$. The TB basile belongs to the genus Mycobacterium of Mycobacteriaceae family of Actinomycetia strain taxonomically. Mycobacterium tuberculosis species of Mycobacteria genus, can lead to fatal disease in humans ${ }^{3}$.

The effective fight against TB in our country started in the 1950s. In 1960, Tuberculosis Control Dispensaries (TCD) was established. Under favor of these efforts, the incidence of TB, which was 172 per hundred thousand in 1965 , decreased to 50 per hundred thousand in 1975. The incidence of national TB fell below 30 per hundred thousand in 2000 for the first time. In 2015, the incidence was determined to be 15.7 per hundred thousand ${ }^{4-6}$.

Süreyyapaşa Chest Diseases and Chest Surgery Training and Research Hospital is a reference center and one of the largest bed capacity hospitals in Turkey for the diagnosis and treatment of TB. In this study, we aimed to evaluate the cases admitted to our hospital with TB diagnosis and to conduct a hospital TB surveillance study.

\section{MATERIAL AND METHODS}

The study was planned as a single centered and retrospective. Between January and December of 2007, 1788 patients who were admitted to Süreyyapaşa Chest Diseases and Chest Surgery Training and Research Hospital with the diagnosis of TB were included in the study. Demographic data, residence addresses, clinical data, radiological data, sputum Acid-fast (AF) staining results, culture results, pathology results and 4 major anti TB drug susceptibility test results data obtained from our hospital TB surveillance files, bacteriology laboratory drug resistance database and patient follow-up software (octomed). After the exclution of repeating admissions, a total of 1753 patients were included in the study. Clinical, radiological, bacteriological [sputum AF staining screening and tuberculosis culture (LöwensteinJensen medium)] and/or histopathologically diagnosed (extra pulmonary TB) patients were included in the study. Resistance patterns of M. tuberculosis complex strains isolated from culture to primary antituberculosis drugs [isoniazide $(\mathrm{H})$, rifampicin (R), ethambutol (E), streptomycin (S)] were examined.

\section{Tuberculosis Case Description}

According to the location of $\mathrm{TB}$; pulmonary tuberculosis (PTB) and extra pulmonary tuberculosis (EPTB). According to the results of bacteriological smear; smear or acid fast bacillus positive $[\mathrm{AFB}(+)]$ and smear or acid fast bacillus negative [AFB (-)]. According to previous treatment history; new case, previously treated cases (relapse, treatment after failure, treatment after loss to follow-up, other previously treated), chronic case and other. All patients who had been treated for more than 1 month were defined as previously treated case (PTC). The case definitions were made in accordance with "TB Diagnosis and Treatment Guidelines of the Ministry of Health (2011)" " .

\section{RESULTS}

In the study group, $65.4 \%(\mathrm{n}=1146)$ of the cases were male and $34.6 \%(n=607)$ were female. The male/female ratio was 1.8 and the highest number of cases in both genders were in the 15-24 age group. Of all cases, $81 \%$ were PTB $(76.5 \%$ new case PTB), $18.9 \%$ EPTB (pleural TB $86.1 \%$, TB lymphadenitis $10.6 \%$ ). The rate of AFB (+) in patients with PTB was $78.7 \%$. It is found that TB culture contributed $8.7 \%$ for the diagnosis.

Total primary and secondary drug resistance were most commonly found against $\mathrm{H}$; respectively $20.2 \%$ and $34.7 \%$. Total primary and secondary resistance for $\mathrm{R}$ were $7.6 \%$ and $22.4 \%$; for $\mathrm{HR}$ were $3.2 \%$ and $7 \%$, respectively. Primary resistance against single drug was $15.4 \%$, double drug was $6.0 \%$, three drugs was $1.3 \%$, and four drugs was 
$2.7 \%$. Secondary resistance against single drug was $15.9 \%$, double drug was $10.9 \%$, three drugs was $4.3 \%$, and four drugs was $9.9 \%$. Primary and secondary resistance to multi-drug were detected respectively $7.2 \%$ and $21.2 \%$. In the study group, $70.5 \%$ of the patients who underwent drug susceptibility tests were sensitive to all drugs (Table 1).

Table 1: Single and Multiple Drug Resistance Distributions by Case Definition in Patients with Drug Susceptibility Test

\begin{tabular}{|c|c|c|c|c|c|c|}
\hline \multirow[t]{3}{*}{ RESISTANCE } & $\begin{array}{c}\text { NEW } \\
\text { CASES }\end{array}$ & & $\begin{array}{c}\text { PREVIOUSLY } \\
\text { TREATED CASES } \\
\end{array}$ & & $\begin{array}{c}\text { ALL } \\
\text { CASES } \\
\end{array}$ & \\
\hline & $\mathrm{n}=884$ & & $\mathrm{n}=\mathbf{3 0 2}$ & & $n=1186$ & \\
\hline & Number & $\%$ & Number & $\%$ & Number & $\%$ \\
\hline TOTAL SENSITIVE & 658 & 74.4 & 178 & 58.9 & 836 & 70.5 \\
\hline TOTAL RESISTANT & 226 & 25.6 & 124 & 41.1 & 350 & 29.5 \\
\hline H resistant & 94 & 10.6 & 30 & 9.9 & 124 & 10.5 \\
\hline $\mathrm{R}$ resistant & 5 & 0.6 & 6 & 2 & 11 & 0.9 \\
\hline E resistant & 0 & 0 & 0 & 0 & 0 & 0 \\
\hline S resistant & 38 & 4.3 & 12 & 4 & 50 & 4.2 \\
\hline TOTAL SINGLE DRUG & 137 & 15.5 & 48 & 15.9 & 185 & 15.6 \\
\hline HR resistant & 28 & 3.2 & 21 & 7 & 49 & 4.1 \\
\hline HS resistant & 21 & 2.4 & 10 & 3.3 & 31 & 2.6 \\
\hline HE resistant & 2 & 0.2 & 1 & 0.3 & 3 & 0.4 \\
\hline RS resistant & 2 & 0.2 & 0 & 0 & 2 & 0.2 \\
\hline RE resistant & 0 & 0 & 1 & 0.3 & 1 & 0.1 \\
\hline ES resistant & 0 & 0 & 0 & 0 & 0 & 0 \\
\hline TOTAL TWO DRUGS & 53 & 6 & 33 & 10.9 & 85 & 7.4 \\
\hline HRS resistant & 11 & 1.2 & 8 & 2.6 & 19 & 1.6 \\
\hline HRE resistant & 1 & 0.1 & 5 & 1.7 & 6 & 0.5 \\
\hline HSE resistant & 0 & 0 & 0 & 0 & 0 & 0 \\
\hline RSE resistant & 0 & 0 & 0 & 0 & 0 & 0 \\
\hline TOTAL THREE DRUGS & 12 & 1.3 & 13 & 4.3 & 25 & 2.1 \\
\hline HRES resistant & 24 & 2.7 & 30 & 9.9 & 54 & 4.6 \\
\hline
\end{tabular}

H: Isoniazid, R: Rifampicin, E: Ethambutol S: Streptomycin, MDR-TB: Multi-drug resistant tuberculosis, TB: tuberculosis, Total $\mathrm{H}$ primary and secondary resistance; $(20.2 \%, 34.7 \%)$, total $\mathrm{R}$ primary and secondary resistance, $(7.6 \%, 22.4 \%)$, total S primary and secondary resistance; $(10.9 \%, 19.5 \%)$, total E primary and secondary resistance, $(3.0 \%, 12.2 \%)$, total MDR primary and secondary resistance, $(7.2 \%, 21.2 \%)$, n: Number of patients who underwent drug susceptibility testing, Total Sensitivity: Patients sensitive to all drugs, Total Resistant : Patients with at least one resistance. 
Table 2: Resistance Rates to Primary Antituberculosis Drugs in Turkey (19-25).

\begin{tabular}{|l|c|c|c|c|c|c|c|}
\hline Researcher & Year & $\begin{array}{c}\text { Number of Cases } \\
(\mathbf{n})\end{array}$ & $\mathbf{H}$ & $\mathbf{R}$ & $\mathbf{E}$ & $\mathbf{S}$ & $\begin{array}{c}\text { MDR-TB } \\
(\boldsymbol{\%})\end{array}$ \\
\hline Aydin et al. & $2005-10$ & 212 & 6.1 & 0.5 & 2.4 & 5.2 & 4.7 \\
\hline Aliskan et al. & $2005-10$ & $373)$ & 2.9 & 0.5 & 3.2 & 2.1 & 2.1 \\
\hline Uysal et al. & 2010 & 78 & 2.6 & 0.0 & 1.3 & 3.8 & 11.6 \\
\hline Sezer et al. & $2006-10$ & 257 & 15.2 & 5.8 & 6.6 & 2.7 & 4.7 \\
\hline Bozdag et al.. & $2009-13$ & 77 & 5.2 & 10.4 & 9.1 & 2.6 & 14.3 \\
\hline Tas et al. & 2009 & 104 & 12.5 & 7.7 & 5.8 & 0.9 & 5.8 \\
\hline Bozkurt et al.. & 2008 & 4221 & 11.3 & 3.9 & 3.4 & 6.5 & 3.0 \\
\hline Dundar et al. & $2007-8$ & 157 & 13.0 & - & 3,0 & 4.0 & 3.0 \\
\hline Etiz et al. & 2013 & 111 & 13.5 & 1.8 & 2.7 & 8.1 & 1.8 \\
\hline Our study & 2007 & 1753 & 10.6 & 0.6 & 0 & 4.3 & 7.2 \\
\hline
\end{tabular}

n: Number of cases with drug resistance testing, H: Isoniazid, R: Rifampicin, E: Ethambutol S: Streptomycin, MDR-TB: Multi-drug resistant tuberculosis, TB: tuberculosis

When the distribution of the cases according to age groups were examined, it was observed that the highest number of cases were in the 15-24 age group. There was a decrease in the number of cases in advanced ages, but after the age of 65 , there was an increase again. In male cases, the first peak was seen between the ages of 15-24, and the later course was similar to the whole case group. The highest number of cases in women were in the 15-24 age group, the age curve decreases after 45-54 years of age and it was stable after 55 years of age. The lowest number of cases for both sexes was in the 0 4 age group. AFB positivity in male cases was $79.7 \%$ and in female cases $76.6 \%$. New cases of PTB were found to be $79.1 \%$ in males and $84.3 \%$ in females. Percentage of cases who lives in Istanbul was $71.6 \%(n=1255)$. Seventy-one point three percent of the cases who lives out of province $(n=355)$ were male.

Of all cases, $81 \%(n=1422)$ had PTB. Of the cases with PTB, $76.5 \%(n=1088)$ were new cases with PTB, $23.5 \%(n=334)$ were PTC with PTB. The rate of AFB positivity was $75 \%$ in new cases and $90.7 \%$ in PTC.
In this study group, $18.9 \%(n=331)$ of the patients had EPTB. These cases diagnosed histopathologically, no smear or culture positivity was detected. In EPTBs; $86.1 \%$ were found to be pleural TB, $10.6 \%$ were TB lymphadenitis, $1 \%$ were pott $\mathrm{TB}, 0.9 \%$ were miliary $\mathrm{TB}, 0.6 \%$ were TB peritonitis, $0.3 \%$ were TB pericarditis and $0.3 \%$ were cutaneous TB. The rates of male/female with pleural TB were $53.4 \% / 32.6 \%(\mathrm{n}=177 / 108)$ and TB lymphadenitis were $3 \% / 7.3 \%(n=10 / 24)$. The male cases were higher in pleural TB group, while female cases were higher in TB lymphadenitis group.

In 1753 patients, $63.8 \%$ of cases $(n=1119)$ were AFB (+) and $17.3 \%$ of cases $(n=303)$ were AFB (). When only PTB cases were considered, AFB positivity ratio was $78.7 \%$. No growth in culture was observed in $5.1 \%$ of AFB (+) cases. The culture was negative in $58.6 \%$ and positive in $41.4 \%$ of AFB (-) cases. In new cases of PTBs, both AFB (+) and culture (+) case rate was $54.7 \%$, AFB $(-)$ and culture (+) was $7.5 \%$, both AFB (-) and culture (-) was $11.6 \%$ and AFB (+) and culture (-) was $2.7 \%$. Previously treated case of PTBs; both 
AFB (+) and culture (+) was 20\%, AFB (-) and culture $(+)$ was $51.3 \%$, both AFB (-) and culture () was $0.9 \%$ and $\mathrm{AFB}(+)$ and culture (-) was $1.3 \%$.

\section{DISCUSSION}

In recent years, Turkey has taken important steps to combat with TB. The new recording and reporting system is widely used in TCDs. As the direct surveillance treatment strategy (DSTS) has been spread throughout the country, realistic surveillance reports on $\mathrm{TB}$ have begun to be recorded. A restructuring study was initiated, including one dispensary for per 500.000 population and at least one dispensary in each city. By the end of 2016, the number of TCDs was 181. As a result, a significant decrease seems in TB cases in our country in recent years. The total rate of TB cases in our country was 15.7 in 2015 while it was 27.9 in $2007^{6}$.

In our study, male/female case ratio was found to be 1.8. The male female case ratio in WHO data is 1.78. In the report of Tuberculosis Control Department of Ministry of Health (TCDMH), the male /female case ratio was found as 1.86. Our data are similar to the two reports. It is known that the risks of the disease vary among male and female due to biological, social, economic differences and cultural roles. Hormonal factors can affect the immunity and susceptibility to infections. However, it is not possible to explain the difference between male/ female case rates by biological difference alone. The males are more active in the society and that they can benefit more from health services so this might increase the rate of diagnosis in males. It might be difficult for women, especially in the underdeveloped countries, to access to health services due to educational and transportation problems, and sometimes for not allowing their spouses. These factors are considered to affect the number of patients diagnosed and recorded beyond the biological differences. Previous studies reported that the ratio of male/female patients was 2.1 in the passive case finding method but when the active case finding method was used, female patient ratio increased9. These findings suggest that polices should be considered to ensure women's access to health care more easily in the world and in our country.

In our study, when the number of cases was examined according to age groups, it was seen that there was a peak in the number of patients in the 15-24 age group, then the number of cases decreased and a second peak over the age of 65 years. In age group case analysis in men, there is an increasing curve in the 15-24 age group, a decreasing curve in the 25-34 age group, and again increasing curve in the 55-65 age group. The age group analysis of cases in women showed that curve starts to rise in the 15-24 age group then follows a flat line in the following age group then shows a decline in the age group 45-54 years of age and remains stable after 55 years of age. When the distribution of the rate of the patients according to the age groups was examined, the data of TCDMH showed that the rate of cases increased beginning by the 15-24 age group and reached the highest level at the age of 65 years and older 6 . In our study, the decrease after the 15-24 year old peak did not fit with the TCDMH data, however, the patients included in our study were hospitalized patients and those referred from other centers which could have contributed to differences between data of TCDMH and ours.

Age distribution of TB patients is one of the indicators of TB control in the community. In societies where TB could not be controlled well, it is seen that the number of patients in the young age group increased and the disease continued in the socially active people, the children were infected and they got TB by reactivation when they reached adulthood. When TB is controlled well, together with the reduction of TB incidence in young and aged population, the rate of infected children will be decreased but only older people and those infected previously will be TB patient. That is, the age curve in the societies applying the good control program makes peak at older ages and peaks at young ages in the societies that do not have a good control program10,11. The data of our country shows that the peak at young age decreases, the curve increases with age and is at the highest level above 65 years. This result supports the fact that our country is one of the countries implementing good TB control program.

In the case of immunodeficiency, non-pulmonary organ TB rates increase. The most commonly involved organs are the pleural and lymph nodes ${ }^{12}$. In our study, the rate of EPTB was found to be $18.9 \%$. This rate is $17.4 \%$ for men and $22.4 \%$ for women, respectively. In the TCDMH report, these rates were reported as $35.6 \%$ for all cases, and $40.9 \%$ for males and $59.1 \%$ for females. In our study, the rate of EPTB for all patients was lower than the country rate, especially for female patients. In our study, the most common EPTB case was pleural TB, where as in the TCD report extra thoracic lymph node TB was the most 
common case $^{6}$. In our study, pleural TB ratio was $86.1 \%$ in all cases of EPTB and 30.2 in TCDMH report. Since our hospital is a pulmonary hospital, other organ tuberculosis cases such as genitourinary, bone, peritoneum, and central nervous system are not hospitalized in our hospital. On the other hand, pleural TB is the largest group diagnosed in our hospital. In our series, EPTB organ involvement is generally higher in males. However, TB lymphadenitis rate was higher in women $7.3 \%$.

Although there are many methods developed in the diagnosis of TB in recent years, sputum smear is still the most widely used method . Newly developed diagnostic methods did not replace sputum smear in routine use. The sensitivity of sputum smear varies between 40-60\%. The sensitivity further decreases especially in HIV (+) patients, in children and EPTB.However, it is a fast and inexpensive method and allows the identification of infectious patients. In our study, sputum smear all were used in all pulmonary TB cases. AFB (+) was found in $63.8 \%$ of the cases in all of our patients $(n=1119 / 1753)$. When PTB cases were considered, the rate of AFB (+) was $78.7 \%$.

In TCDMH data, the rate of AFB (+) in PTB patients was reported to be $64.0 \%{ }^{6}$. According to WHO criteria among all tuberculosis cases, $50 \%$ should be smear positive, $15 \%$ should be smear negative PTB and $35 \%$ should be EPTB $^{13}$. Accordingly, the rate of smear-positive new case/PTB rate should be approximately $75 \%$. In a study that examined Istanbul Tuberculosis Dispensary results, the rate of AFB (+) cases in 9822 patients with PTB was reported as $55.4 \%$ during 1998 and $2000^{14}$. When compared to these results it is possible to declare that this ratio is higher in our study. This result can be explained by the importance of bacteriological diagnosis in our hospital and the experience of our technicians working in bacteriology laboratory.

The routine method used in the diagnosis of TB is direct microscopy. However, the gold standard diagnostic method is culture. There are different solid and liquid media used for tuberculosis culture. Löwenstein-Jensen medium is the medium used in daily practice at our hospital. In this study every sputum samples was sown on the Löwenstein-Jensen medium for culture following direct smear. Among $41.4 \%$ of the patients with smear (-), reported as culture (+). The prevalence of smear positivity in patients with PTB was $78.7 \%$, while the rate of culture positivity was $83.5 \%$. In our study, culture contributed to the diagnosis of TB at a rate of $8.8 \%(n=125)$. However, in 68 patients, there was no reproduction in culture. All of these patients were diagnosed with TB. In patients receiving $\mathrm{TB}$ treatment, bacillis lose their vitality, but they may not be propagated in culture even though they are seen in the smear. Some of our patients were referred to our center after treatment was started. In patients who are not treated, excessive exposure to daylight during the preparation of sputum, inadequate processing errors such as overheating or lack of medium may be the cause of false negativity in culture. In previous studies, it has been reported that approximately $4 \%$ of the AFB (+) patients can be culture negative ${ }^{15}$.

Many reports have been prepared to evaluate the rates of resistance to tuberculosis drugs in our country and in the world. Inadequate differential diagnosis (primary resistance?, secondary resistance?) and lack of standardized laboratory systems reveal inadequate data about TB drug resistance in the world and resistance to $\mathrm{TB}$ remains a significant problem. Bozkurt et al. in their study on 4221 cases, found that the rate of primary resistances to $\mathrm{H}, \mathrm{R}, \mathrm{E}, \mathrm{S}$ and multi-drug were $(11.3 \%, 3.9 \%, 3.4 \%, 6.5 \%$ and $3.0 \%)$ respectively ${ }^{16}$. Our study has similar results with this study. In our study, primary and secondary drug resistances were most frequently against to $\mathrm{H}$ $(20.2 \%, 34.7 \%)$ followed by S $(10.9 \%, 19.5 \%)$, R $(7.6 \%, 22.4 \%)$ and $\mathrm{E}(3.0 \%, 12.2 \%)$. Primary and secondary multi-drug resistances were determined as $7.2 \%$ and $21.1 \%$. The rates of primary and secondary resistance against to $\mathrm{H}, \mathrm{R}, \mathrm{E}$ and $\mathrm{S}$ were found to be higher than data of TCDMH except for the secondary resistance rate of S. In two studies conducted in our country, the rates of primary resistance vary between $19.2 \%$ and $38.2 \%$ and the rates of secondary resistance are reported to vary between $42.2 \%$ and $68.5 \%{ }^{17,18}$. These results show that there are significant differences between the centers where the studies are conducted. Drug susceptibility tests in tuberculosis are tests to be performed in advanced laboratories. Therefore, the results of susceptibility tests performed in different laboratories in different centers also have significant differences. However, our hospital is one of Turkey's largest chest diseases hospital and is considered as a reference center. Therefore, referral of many patients from other provinces and TCDs, especially multi-drug resistance TB patients to our center, also leads to an increase in drug resistance rates in our hospital.

The limitations of our study were retrospective, lack of information in some patient file records, 
and lack of information about mortality in patient records. In conclusion, this study, in which 1753 TB patients were screened, is one of the largest studies in Turkey. AFB (+) rates in patients with PTB were found to be higher than the data of our country. Drug resistance rates were found to be high due to referral of multidrug-resistant cases to our center. Another important result of our study is the fact that the diagnosis and resistance rates of our hospital, which is a TB reference center, have been reflected. We believe that the results of our study may be the guide for the next comprehensive studies.

\section{Acknowledgements:}

We thanks to our hospital staff for helping to collect data about patient.

\section{Conflict of interest:}

There is no conflict of interest.

\section{REFERENCES}

1. World Health Organization website. http://apps.who.int/iris/bitstream/handle /10665/274453/9789241565646eng.pdf?ua=1.

2. Kilıçaslan Z. Akciğer Hastalıkları: İ.Ü.İstanbul Tıp Fakültesi Temel ve Klinik Bilimler Ders Kitapları İstanbul : Nobel Tip Kitabevleri, 2002:283-287.

3. Iseman Md. A Clinician's Guide To Tuberculosis .1st Ed Philadelphia: Lippincott Williams \&Wilkins 2000:21-49.

4. Koçoğlu F. Verem Savaşı Ankara: Hacettepe Üniversitesi Tıp Fakültesi Halk Sağlığ Anabilim Dalı Yayını 1986;36-86.

5. Özcan C. "Türkiye'de tüberkülozun bugünkü durumu." Ankara: Türkiye'de Sağlık ve Tedavi Vakfi, Semih Ofset Matbaacilık Ltd. Şti (1988): 5-10.

6. https://hsgm.saglik.gov.tr/depo/haberler/vere m-savas-raporu-2016-2017/Turkiyede_ Verem_Savasi_2017_Raporu.pdf.

7. Tüberküloz Tanı ve Tedavi Rehberi, Sağlık Bakanlığı Yayın No: 862, Ankara: 2011.

8. http://apps.who.int/iris/bitstream/handle/1066 5/274453/9789241565646-eng.pdf?ua $=1$.

9. Johansson, E., Long, N. H., Diwan, V. K., \& Winkvist, A. (1999). Attitudes to compliance with tuberculosis treatment among women and men in Vietnam. The International Journal of Tuberculosis and Lung Disease, 3(10), 862-868.

10. Rieder, Hans L. Epidemiologic basis of tuberculosis control. No. Ed. 1. International Union Against Tuberculosis and Lung Disease (IUATLD), 1999.
11. Çalışır H, Toraks Derneği Ulusal akciğer Sağlığ 1 Kongresi , Tüberküloz tanı ve Tedavisi ders Notları, sayfa 62.

12. Luna, José A. Caminero. A tuberculosis guide for specialist physicians. International Union Against Tuberculosis and Lung Disease, 2004.

13. Çiftçi F, Bozkanat E, İlvan A, ve ark. Referans özelliği olan bir askeri hastanede tüberkülozlu asker hastaların 2003 yılı tedavi sonuçları. Toraks Derg. 2006;7(1):45-50.

14. Kılıçaslan Z; Öztürk F, Sarımurat N Et. Al. Microcopic Examination An Treatment Outcomes Of New Pulmonary Tuberculosis Cases İn İstanbul Dispensaries Between 1998-2000. Int J Tuberc Lung Dis 2003; 7(11):1059-1063.

15. Toman, Kurt. Toman's Tuberculosis: case detection, treatment, and monitoring: questions and answers. World Health Organization, 2004.

16. Bozkurt H, Türkkanı MH, Musaonbaşıŏlu S, ve ark. Türkiye geneli tüberküloz verileri, Ankara: T.C. SağlıkBakanlığı Verem Savaşı Daire Başkanlığı [TB2010 Report in Turkey]. 2010:37-41.

17. Çoban G., Akkalyoncu B., Şipit T., Berktaş B., Dursun B., Gözü A. (2000). AGHH'de 1997 yılında tüberküloz ilaç direnç oranları. Solunum Hastalıkları, 11, 388-395.

18. Talay F., Altın S., Çetinkaya E., Kümbetli Ş. (2003). İstanbul Eyüp Verem Savaş Dispanseri'ndeki Tüberküloz hastalarının değerlendirilmesi. Van Tıp Dergisi, 10(2), 4045.

19. Aydın F, Kaklıkkaya N, Bayramoğlu G, ve ark. Klinik örneklerden izole edilen Mycobacterium tuberculosis kompleks suşlarının antibiyotiklere direnç oranları. Mikrobiyol Bul. 2011;45(1):36-42.

20. Alışkan HE, Bostanoğlu E, Turunç T, ve ark. Retrospektif olarak tüberküloz laboratuvarının altı yıllık sonuçları ve antimikobakteriyel ilaçlara direnç oranları. Turk Toraks Derg. 2013;14(2):53-8.

21. Uysal EB, Kaya H. Klinik örneklerden izole edilen Mycobacterium tuberculosis kompleks suşlarının majör anti-tüberküloz ilaçlara duyarlılıkları. Tıp Araştırmaları Dergisi. 2014;12(2):67-70.

22. Sezer O, Çiçtçi F, Kutlu A, ve ark. Yeni olgu, genç erişkin, tüberkülozlu erkek hastalarda ilaç direnç oranları. Turkiye Klinikleri J Med Sci. 2012;32(1):139-45. https://doi.org/ 10.5336/medsci.2011-23362.

23. Bozdağ İ, Coşar AD, Uysal EB, Özer A. Klinik örneklerden izole edilen 
Mycobacterium tuberculosis kompleks suşlarının antibiyotiklere direnç oranları. Tıp Araştırmaları Dergisi. 2015;13(1):6-10.

24. Taş D, Taşçı C, Demirer E, Sezer O, Okutan O, Kartaloğlu Z. Genç askerlerde tüberküloz insidansı ve primer ilaç direnci oranları: ülkemizdeki 14 asker hastanesinin verileri. Mikrobiyol Bul. 2012;46(1):26-32.

25. Dündar D, Sönmez-Tamer G. Mycobacterium tuberculosis kompleksi izolatlarının primer antitüberküloz ilaçlara direnç oranları. Klimik Derg. 2009;22(2):524. 